\title{
ADDITIONS TO MY SYNOPSIS OF THE TACHINIDAE.
}

BY D. W. COQUILletT, WASHINGTON, D. C.

Since the publication of the above work several additional forms have been examined, the result of which is recorded herewith. Dr. S. H. Scudder kindly presented to the National Museum co-types of his Tachina theclarum, and of many of the species described in his work on the Butterflies of New England; in every case these conform to the positions assigned them in my Synopsis.

Clistomorpha .hyalomoides, Townsend, is a synonym of Xysta didyma, Loew. It belongs to the genus Clytiomyia, of which Clistomorpha is therefore a synonym.

Cistogaster pallasii, Townsend, Proc. Ent. Soc., Washington, 1891, page 142. This reference was inadvertently omitted in the Synopsis. 1 have not seen a specimen which agrees with this description.

Admontia hylotomae, n. sp.- $\hat{o}$. Black, the palpi and apex of proboscis yellow. Front at narrowest part two-thirds as wide as either eye, no orbital bristles, frontals descending to middle of second antennal joint, antennae five-sevenths length of face, the third joint nearly twice as long as the second, arista thickened on the basal third, the penultimate joint broader than long; sides of face at narrowest part each nearly one half as wide as the median depression, bearing numerous bristly hairs, cheeks one-third as broad as the eye-height, vibrissae slightly above the oral margin, ridges bristly on the lowest third. Thorax gray pruinose, marked with four black vittae; three postsutural and three sternopleural macrochaetae, scutellum bearing three pairs of long marginal and a short apical pair. Abdomen polished, last three segments gray pruinose at their bases, bearing discal and marginal macrochaetae. Wings hyaline, slightly tinged with yellow along the veins, third vein bearing two or three bristles near the base; calypteres whitish. Hind tibiae outwardly subciliate, front pulvilli as long as the last tarsal joint, tarsi not dilated.

$q$ Differs from the $\delta$ as follows: Front as wide as either eye, two pairs of orbital bristles, third segment of abdomen carinate on the under side, the carina thickly beset with short spines; front pulvilli one-half as long as the last tarsal joint.

Length, 6 to $9 \mathrm{~mm}$. Woods Holl, Mass. Bred from Hylotoma humeralis, Beauv., by Dr. Harrison G. Dyar. Three males and five females. Type No. 4061, U. S. Nat. Museum. 
Admontia unispinosa, n. sp.- - . Differs from the $q$ of hylotomae as follows: Apex of proboscis black. Front slightly wider than either eye, frontals descending only a short distance below base of second antennal joint, antennae four-fifths as long as the face, the third joint from three to four times as long as the second, arista thickened on the basal half, sides of face each one-fifth as wide as the median depression, bearing a single row of bristly hairs, vibrissae at the oral margin. Abdomen bearing only marginal macrochaetae, destitute of spines on the under side. Wings not tinged with yellow along the veins, third vein bearing a single bristle near its base. Length, 4 to $6 \mathrm{~mm}$. Opelousas, La. Eight specimens collected in June, 1897, by Mr. G. R. Pilate, and submitted by Dr. Garry de $N$. Hough. Type No. 4062, U. S. Nat. Museum.

Admontia tarsalis, n. sp.- $q$. Differs from $q$ of hylotomae as follows: Apex of proboscis brown, basal half of antennae yellow. Front one-fifth wider than either eye, antennae as long as the face, the third joint five times as long as the second, sicles of face each one-fifth as wide as the median depression, bearing a row of macrochaetae in continuation of the frontal row, vibrissae on a level with front edge of oral margin, ridges bristly on the lower half. Abdomen destitute of spines on under side. Front tarsi toward the apex greatly dilated. Length, 5 to $6 \mathrm{~mm}$. Opelousas, La. Two specimens collected in May and June, 1897, by Mr. G. R. Pilate, and submitted by Dr. Garry de N. Hough. Type No. 4063, U. S. Nat. Museum.

Admontia polita, n. sp. - . Differs from the description of hylotomae $q$ as follows: Second joint of antennae yellow, apex of proboscis brown. Frontal bristles descending only slightly below base of second antennal joint, antennae almost as Iong as the face, the third joint three times as long as the second, sides of face each one-third as wide as the median depression, bearing a row of macrochaetae, vibrissae on a level with front edge of oral margin, only two or three bristles above each. Thorax polished, not pruinose except along the sides, scutellum destitute of a short apical pair of macrochaetae. Abdomen not pruinose on the fourth segment, destitute of spines on the under side, discal macrochaetae sometimes wanting. Length, 5 to $7 \mathrm{~mm}$. Oswego, N. Y. (July 1 and 17, 1897; Prof. Chas. S. Sheldon), and Jacksonville, Fla. (Mrs. A. T. Slosson). Seven specimens.

Dionaea, Desv. (Synonym, Labidigaster, Macq.) - This genus falls 
in the last couplet in my synoptic table, and will be recognized by having a single bristle at base of the third vein, the head one and one-third times as high as long, and the proboscis only once geniulate.

Dionaea nitoris, n. sp. $-\hat{o}$.. Black, the palpi yellow. Front of male one-fifth, in the female four-fifths, as wide as either eye, frontal bristles not descending beneath the base of second antennal joint, two pairs of orbital bristles in the female, wanting in the male, antennae threefourths as long as the face, the third joint one and one-half times as long as the seoond, arista thickened on the basal third; vibrissae slightly above the level of the front edge of the oral margin, one or two bristles above each. Thorax polished, a median vitta in front of the suture and the lateral margins, whitish pruinose, three postsutural and two sternopleural macrochaetae, scutellum bearing three long marginal pairs. Abdomen polished, without a trace of gray or whitish pruinosity, first segment one and one-half times as long as the third, the first three bearing only marginal macrochaetae, last segment in the female provided at its apex with a pair of curved appendages resembling a pair of pincers. Tarsi not dilated, front pulvilli of male slightly longer than, in the female scarcely one-half as long as, the last tarsal joint. Wings gray, toward the base yellowish, along the posterior margin subhyaline, calypteres white. Length, $5 \mathrm{~mm}$. Corvallis, Oregon. A specimen of each sex collected July 16 and Sept. 16, 1896, by Mr. A. B. Cordley. Type No. 4065, U. S. Nat. Museum.

Chaetophleps rostrata, n. sp. - . Black, the lower part of the face and apex of proboscis, yellow. Front slightly wider than either eye, two pairs of orbital bristles, frontals descending to middle of second antennal joint, antennae nearly as long as the face, the third joint four times as long as the second, arista thickened almost to the middle, face in profile strongly concave, vibbrissae on a level with front edge of oral margin, two or three bristles above each, proboscis slender, the labella considerably prolonged backward. Thorax gray pruinose, marked with four black vittae; three postsutural and two sternopleural macrochaetae, scutellum bearing three marginal pairs. Abdomen polished, bases of last three segments gray pruinose, each segment bearing only marginal macrochaetae, venter destitute of short, stout spines. Tarsi not dilated, hind tibiae not ciliate. Wings hyaline, first vein bristly on its apical third, the third bearing three bristles near its base, calypteres white. Length, $3 \mathrm{~mm}$. Biscayne Bay, Fla. (Mrs. A. T. Slosson), and Opelousas, La. (Mr. G. R. Pilate). Three specimens. Type No. 4066, U. S. Nat. Museum. 
Hypostena setinervis, n.sp.- - . Black, the palpi, apex of proboscis, abdomen, coxae, femora and tibiae, yellow, the last two segnents of the abdomen partly tinged with brown. Front as wide as either eye, two pairs of orbital bristles, frontals descending to apex of second antennal joint, antennae as long, as the face, the third joint six times as long as the second, arista thickened almost to the middle, vibrissae on a level with tront edge of oral margin, ridges bristly on the lowest fourth. Thorax gray pruinose, marked with four black vittae; four postsutural and two sternopleural macrochaetae, scutellum bearing three pairs long marginal and a short apical pair. Abdomen polished, bases of last three segments whitish pruinose, first three segments bearing only marginal macrochaetae, venter destitute of short, stout spines. Tarsi not dilated, hind tibiae subciliate. Wings hyaline, third vein bristly to slightly beyond the small cross-vein, hind cross-vein nearer to the small than to bend of fourth vein, calypteres white. Length, $5 \mathrm{~mm}$. Biscayne Bay, Florida. A single specimen collected by Mrs. A. T. Slosson. Type No. 4067, U. S. Nat. Museum.

Exorista dorsalis, n. sp.- $q$. Black, the palpi and sometimes the sides of the abdomen, except at each end, yellow. Front from three-fifths to two-thirds as wide as either eye, two pairs of orbital bristles, frontals descending to apex of second antennal joint, sides of face and of front in front of the orbitals silvery-white pruinose, antennae nearly as long as face, the third joint from three to four times as long as the second, arista thickened on the basal two-fifths, the penultimate joint only slightly longer than broad, facial ridges bristly on the lowest two-fifths, cheeks one-sixth as broad as the eye-height. Thorax polished, having a strong brassy tinge, without a trace of light coloured pruinosity on the dorsum; three postsutural and three sternopleural macrochaetae, scutellum bearing three pairs of long marginal and a short apical pair. Abdomen somewhat polished, thinly gray pruinose, last three segments bearing discal as well as marginal macrochaetae. Hind tibiac outwardly cilitate, middle tibiae each bearing a single macrochaeta on the front side near the middle. Wings hyaline, third vein bearing from two to four bristles near its base, bend of fourth vein destitute of an appendage, calypteres whitish. Length, 6 to $7 \mathrm{~mm}$. North Mt., Pa. (Sept. 2, 1897; Mr. C. W. Johnson), and Ga. Two specimens. Type No. 4068, U. S. Nat. Museum.

Brachycoma Sheldon, n. sp.- $\hat{\sigma}$ ơ. Black, a subtriangular spot outide of each vibrissa, brown, a yellow ring on the arista beyond the thick: ned base. Front of male one-fourth as wide as in the female, as wide as 
either eye, two pairs of orbital bristles in the female wanting in the male, frontals descending almost to base of second antennal joint, sides of face bearing bristly hairs, and on the lower portion with several macrochaetae, antennae from slightly over two-thirds to three-fourths as long as the face, the third joint only slightly longer than the second, arista long pubescent on basal half, thickened on the basal fifth, vibrissae on a level with front edge of oral margin, two or three bristles above each, cheeks three-fifths as broad as the eye-height. Thorax gray pruinose, marked with three black vittae; three postsutural and three sternopleural macrochaetae, scutellum bearing three long marginal pairs. Abdomen somewhat polished, gray pruinose and with darker reffecting spots, last three segments bearing only marginal macrochaetae. Middle tibiae each bearing two or three macrochaetae on the front side near its middle, front pulvilli of male as long as the last tarsal joint. Wings hyaline, tinged with yellow at the base, costal spine Ionger than the small cross-vein, third vein bristly at least half-way to the small cross-vein, calypteres white. Length, 8 to $10 \mathrm{~mm}$. Oswego, N. Y. One male and three females collected in July and August, 1895 and 1896, by Prof. Charles S. Sheldon, after whom the species is named. Type No. 4069 , U. S. Nat. Museum.

\section{ON SOME SMALL BEES FROM ARIZONA.}

BY T. D. A. COCKERELL, MESILLA, N. M.

Some time ago Prof. C. F. Baker sent me a lot of small bees collected by Dr. R. E. Kunzé at Phoenix, Arizona, May 12, 1897, "on willows and various low herbs." I have examined these with interest, as they belong to genera not recorded from that region; they prove to be as follows :

(1.) Perdita salicis, Ckll., 1896.- $\hat{\delta} \cdot$. + . Very many specimens.

(2.) Prosapis messilae, CkI1., 1896.-A few, mostly males.

(3.) Halictus meliloti, Ck11., 1895.-One .

(4.) Halictus pseudotegularis, Ckll., 1896.-On April 12, 1897, I took at flowers of Sisymbrium, in Messilla, N. M., a single Halictus which differed decidedly from Illinois $H$. tegularis, but, to my surprise, almost agreed with the Mexican $H$. pseudotegularis, except that the wings were clear. Now, among the Arizona bees I find examples of pseudotegularis with slightly dusky wings, as in the type of that species; the second submarginal cell is noticeably smaller than in tegularis, and receives the recurrent nervure further from its end. 